\title{
"VESTIRME DE HOMBRE Y MONTAR A CABALLO". ANDROGINIA Y MUJER MODERNA EN LA NOVELA AUTOBIOGRÁFICA OCULTO SENDERO, DE ELENA FORTÚN
}

\author{
Purificació Mascarell \\ Universitat de València \\ purificacio.mascarell@uv.es
}

\section{Resumen}

La escritora Elena Fortún (Madrid, 1886-1952) es célebre por su mítico personaje de ficción para nińos: la imaginativa y traviesa Celia. Este artículo pretende analizar la obra más alternativa de la autora, Oculto sendero, publicada por primera vez en 2016 tras décadas escondida en una maleta: la autora no la quiso publicar en vida. Se trata de una obra de corte autobiográfico donde Fortún usa el personaje de la pintora María Luisa Arroyo para hablar de su propio proceso de descubrimiento de una orientación sexual que una madre autoritaria, el matrimonio y la presión social le impidieron vivir plenamente. Este artículo estudia el vínculo entre el concepto de "mujer moderna» y la adopción de una estética andrógina, a partir de la historia de María Luisa.

Palabras clave: autobiografía, mujer moderna, androginia, Elena Fortún, lesbianismo.

\author{
"DRESS UP AS A MAN AND RIDE A HORSE." ANDROGYNY \\ AND MODERN WOMAN IN THE AUTOBIOGRAPHICAL \\ NOVEL OCULTO SENDERO, BY ELENA FORTÚN
}

\section{Abstract}

The writer Elena Fortún (Madrid, 1886-1952) is famous for her paradigmatic fictional character for children: the imaginative, frisky Celia. This article aims to analyze the most alternative work of the author, Oculto camino, published for the first time in 2016 after decades hidden in a suitcase: the author did not want to have it published while she was alive. It is an autobiographical work where Fortún uses the character of the painter María Luisa Arroyo to talk about her own process of discovering a sexual orientation that an authoritarian mother, marriage and social pressure prevented her from fully living. This article studies the link between the concept of «modern woman» and the taking up of an androgynous aesthetic, based on the story of María Luisa.

KEYwORDS: autobiography, modern woman, androgyny, Elena Fortún, lesbianism.

DOI: https://doi.org/10.25145/j.clepsydra.2021.21.01

Revista Clepsydra, 21; marzo 2021, pp. 17-33; ISSN: e-2530-8424 
Cuando Marisol Dorao regresaba de los Estados Unidos a finales de los ochenta abrazada a la vieja maleta que contenía el manuscrito inédito de Oculto sendero ${ }^{1}$, la biógrafa de Elena Fortún estaba muy lejos de imaginar que, treinta años después, ese texto de corte autobiográfico se convertiría en uno de los más representativos de la literatura homosexual española. En concreto, esta obra se erige como la novela de tema lésbico más interesante de nuestras letras modernas. Sin embargo, la autora nunca llegó a reconocer abiertamente su orientación sexual, de hecho, esta se intuye más que se confirma cuando leemos su correspondencia con amigas como la grafóloga Matilde $\operatorname{Ras}^{2}$ o Inés Field ${ }^{3}$, cuya amistad trascendía la común y corriente para Encarnación Aragoneses -auténtico nombre de la creadora de la saga de Celia-. En cualquier caso, el título de Oculto sendero, ese camino vedado a las acusadoras miradas ajenas, alejado de lo público y vinculado al ámbito más íntimo y profundo del ser, expresa a la perfección el tipo de vivencia del lesbianismo que, con toda probabilidad, experimentó Fortún.

Nuria Capdevila-Argüelles (Oculto 59) habla de la implicación de Elena en el denominado Círculo Sáfico de Madrid, un grupo de mujeres lesbianas que se reunía para compartir su amor por la cultura y el arte durante los años treinta en la capital española. La novela Acrópolis (1984), de Rosa Chacel, retrataría ese ambiente y la tipología de sus miembros, supuestamente liderados por la escenógrafa Victorina Durán ${ }^{4}$. En los últimos compases de Oculto sendero también se describe un submundo madrileño de bohemia, literatura y pintura, con gais y lesbianas en tertulias impregnadas de música vanguardista, humo de cigarro y seducciones a varias bandas. Tenemos que imaginar a Elena Fortún, en su exilio bonaerense, junto a un marido inadaptado y depresivo, trabajando como bibliotecaria gracias a la ayuda de Jorge Luis Borges y rememorando su vida desde la infancia, incluidos esos ańos de libertad antes de que la guerra arrasara con todo: un pasado real que sirve de base para construir la ficción de Oculto sendero; una Elena que se mimetiza en la protagonista, la pintora María Luisa Arroyo. Y, luego, tenemos que imaginarla regresando a la España franquista para pasar sus últimos años y pidiendo a Inés Field que se deshiciera de ese texto perturbador, que nunca hubiera querido ver publicado, al

${ }^{1}$ La peripecia de la recuperación de este y otros materiales de Fortún (permanecían en poder de Anne Marie Hug, la nuera estadounidense de Elena y la persona que se los brinda a Dorao), se cuenta en Los mil sueños de Elena Fortún (1999).

2 Pueden consultarse, a este respecto, los volúmenes El camino es nuestro (2015) y el Diario (2018), de Matilde Ras.

${ }_{3}$ Nuria Capdevila-Argüelles ha editado la correspondencia entre Elena y su amiga argentina en los volúmenes Cartas a Inés Field, I. Sabes quién soy y Cartas a Inés Field, II. Mujer doliente, que la editorial Renacimiento publicará en breve.

${ }^{4}$ Gracias a la reciente edición de la Residencia de Estudiantes en tres cuidados tomos (2018), podemos leer las fascinantes memorias de esta apasionante mujer de la Edad de Plata. Sin embargo, las editoras declaran que les ha sido imposible encontrar documentos o fuentes que confirmen la existencia de dicho Círculo. ¿Cuán ocultas serían las reuniones de esta asociación que no han dejado huellas fehacientes? 
que nunca debiéramos haber tenido acceso y que Elena quiso firmar bajo otro seudónimo: Rosa María Castaños. Máscara sobre máscara.

¿Qué narra Oculto sendero? El largo y duro proceso de autoconocimiento de su protagonista, María Luisa Arroyo, una niña criada a finales del siglo XIX bajo el corsé tradicional de una madre autoritaria y en una sociedad patriarcal que impide su desarrollo intelectual, profesional y sexual. Una nińa que pasa a ser una adolescente aterrada ante la obligatoriedad del matrimonio y ante la violencia de la sexualidad masculina; una joven que accede a casarse con el pintor Jorge Medina porque parece la mejor salida a su claustrofóbica situación. Como muchas mujeres que desean escapar de madres asfixiantes y acaban en manos de maridos machistas -patrón clásico en la historia de la mujer española-, María Luisa tendrá que someterse a un nuevo "ordeno y mando»: el de un artista ególatra y celoso que exige de su esposa un comportamiento sumiso típicamente femenino y que nunca comprenderá la complejidad del alma de su compañera y sus deseos de realización personal. María Luisa irá descubriendo, a medida que pasen los ańos de matrimonio, lo alejada que está de cumplir adecuadamente con el rol social de esposa y madre: a ella le interesa leer, aprender, crear, pintar, conversar con personas que conectan con su extrema sensibilidad y sus gustos culturales. Al final de la novela, tras algunas relaciones amorosas con mujeres que acaban en fracaso, agotada de llevar una doble vida, María Luisa decide divorciarse y emprender una nueva vida en América.

En este trabajo, nos interesa la construcción de la identidad del personaje de María Luisa a través del vestuario masculinizante y de la estética andrógina, tan recurrente a lo largo de toda la novela: un leitmotiv que refuerza la idea de «diferencia» y extrańeza respecto a la norma que caracteriza a la protagonista y que la incardina dentro de la categoría de «mujer moderna» o «mujer nueva», como se mostrará en la parte final de este ensayo.

La importancia vital del vestuario y sus connotaciones está presente desde el primer capítulo de Oculto sendero, titulado, significativamente, «El vestido». María Luisa es una nińa sensible, solitaria, permanentemente atemorizada por los adultos que la rodean, principalmente por una madre de corte decimonónico que percibe a su hija como «un chicazo» al que hay que doblegar para que entre en el corsé femenino diseñado por la sociedad patriarcal. La autobiografía de María Luisa se inicia con uno de sus más terribles recuerdos infantiles: el día en que su madre le regala un vestido con puntillas de encaje en vez del traje de marinero que a ella le hacía tantísima ilusión.

- El vestido... el vestido -sollocé desesperada-, el vestido que no era así... ¡No lo quiero! No me lo pondré nunca... No lo quiero... [...] Yo dije... yo dije -seguía sollozando-, que el traje tenía que ser de marinero... con gorra y todo, y tú decías que... que bueno... y ahora... - y ya no me fue posible continuar porque a mi dolor le habían nacido nuevas aristas y ya no me cabía en el cuerpo que se dobló convulso sobre las rodillas (74).

La niña María Luisa sufre un auténtico acceso de pánico ante la perspectiva de tener que adoptar el atuendo de una «mujercita». Las puntillas que decoran el 
vestido son como puñales que se clavan en la identidad en construcción de la criatura, incomprendida por toda su familia, que la obliga a vestir al gusto de la madre. Vestuario y división en dos sexos asimilados a dos géneros van de la mano e imponen un binarismo en el cual no se siente a gusto esta niña con trazas de "chico» que avanza hacia una adolescencia en la cual deberá mostrarse, ya definitivamente, con todos los atributos tópicos de la feminidad. En este sentido, resulta de gran interés la aportación de Judith (ahora Jack) Halberstam en su ensayo Masculinidades femeninas:

El chicazo tiende a asociarse a un deseo «natural» por esa mayor libertad y movilidad de que disfrutan los hombres. Muy a menudo se interpreta como un signo de independencia y automotivación, y la conducta del chicazo puede incluso ser alentada, hasta el punto de quedar vinculada cómodamente a un sentido estable de la identidad de chica. Sin embargo, la conducta del chicazo se castiga cuando se convierte en el indicador de una fuerte identificación con el varón (ponerse un nombre de chico o negarse a vestir cualquier tipo de ropa de chica) y cuando amenaza con prolongarse más allá de la infancia, en la adolescencia. La adolescente chicazo supone un problema y suele ser objeto de severos esfuerzos para su reorientación (28).

Interesante es ver también hasta qué punto las mujeres con vestimenta y estética masculinas atraen sexualmente a María Luisa desde bien pequeña. El segundo capítulo de la obra se titula «El restaurant» y recoge, precisamente, un momento epifánico en el proceso de descubrimiento de la orientación sexual de la narradora, pese a que María Luisa aún tardará muchos años en racionalizar su lesbianismos. Toda la familia Arroyo marcha a comer a un restaurante para celebrar el aniversario de boda de los padres. La nińa va vestida con el odiado traje de puntillas, con el que se siente tan a disgusto, pero «de pronto dejé de ver todo lo que me rodeaba para mirar las escaleras de mármol por donde descendían dos muchachas... dos señoritas, diría yo. ¡Dios mío, qué señoritas!» (80). La descripción que se ofrece de la pareja las sitúa en las categorías de butch-lesbiana de aspecto masculino, en el caso de la de pelo oscuro-y femme-lesbiana femenina, para la de cabello claro- ${ }^{6}$. Merece la pena recoger el fragmento aquí:

5 Aunque en la época de la acción de la novela se hablaría en términos clínicos más bien de «inversión» o de «intersexualidad» (Marañón 1930) para referirse a la orientación sexual lesbiana de María Luisa, en este ensayo optamos por utilizar la terminología de la teoría de género contemporánea con el objetivo de resaltar el vínculo con la modernidad de este texto de Fortún. Para conocer la teoría sexológica de principios del siglo xx en relación con la producción literaria de aquel momento, merece la pena acercarse al trabajo de Beatriz Celaya Carrillo (2006).

${ }^{6}$ Esta aparente copia de los roles o estereotipos de la pareja hombre-mujer heterosexual se observa con frecuencia en las parejas de lesbianas de las primeras décadas del xx, como recoge el trabajo de Matilde Albarracín. Las que adoptaban una estética masculina «vestían pantalones anchos, camisa, chaleco y/o chaqueta; también utilizaban calzado de hombre y sombrero. Solían llevar el pelo corto, al uso de la época, con grasa para que diese brillo. Se vestían a la moda dandi, siguiendo el modelo de algún cantante o actor de la época, como Gardel, Valentino o Negrete» (76). 
Una era morena, llevaba el pelo corto como un hombre y pegado a la cabeza, como mi hermano Ignacio, pero su cabecita era pequeńa y redonda, los ojos grandes y aterciopelados y los labios muy rojos... Su traje era lo más original y envidiable... Chaqueta gris con solapas como la de cualquier hombre, camisa de seda, corbata y falda corta y ajustada... La otra señorita era rubia y su vestido de terciopelo azul debía de ser precioso, pero solo recuerdo su cutis blanquísimo, y los rizos que le caían sobre las orejas. [...] Por debajo de la mesa veía sus pies. Los de la rubia calzados con primorosos zapatos de tacón alto en los que había incrustados brillantes... ¡Qué maravilla! Los de la morena eran planos, pequeños, fuertes como los de un hombre... ¡ Oh, pero no como los de mi padre y mis hermanos...! Las piernas de la morena, fuertes y musculosas estaban cubiertas por medias de seda gris... (80-81).

La visión obnubila a María Luisa y la deja sin apetito. Solo tiene ojos para mirar a las dos chicas que, por si su aspecto no fuera lo suficientemente transgresor, se atreven a fumar en público. Pronto los padres de María Luisa también se percatan de la presencia de esta pareja «anómala» en el comedor y la madre comenta: «- Pero, ¿qué es eso? Parece una mujer disfrazada, pero que no tiene pelo, ni pendientes... ¡Qué cosas, señor!» (82). El demostrativo neutro «eso», sin la terminación de género masculina o femenina, viene a reforzar la idea de «inclasificable» dentro de los dos compartimentos estancos que maneja el pensamiento tradicional asumido por la madre. Que a la muchacha le falten dos elementos tan básicos de la feminidad como la cabellera larga y los pendientes en los lóbulos de las orejas viene a reforzar la idea de que el género es un constructo, muchas veces, puramente visual. De hecho, la familia de María Luisa está convencida de que la chica morena es un hombre homosexual hasta que el camarero les saca del error: ${ }^{7}$ "- Es una mujer, señor... Creo que escribe coplas... versos, me parece, y es americana... La otra es su secretaria» (85). Son extranjeras, viven del arte, viajan sin familia, trabajan y gastan su propio dinero, se aman ante las miradas ajenas... Representan todo lo que María Luisa, en su ambiente pacato y limitado, es incapaz de imaginar para su futuro, pero ya comienza a ambicionar sin conocerlo.

La ambigüedad de la mujer que adopta rasgos típicamente masculinos, la perturbación que causa toda figura andrógina - esa confusión de la lesbiana masculina con un hombre gay- está en la base lúdica de los dibujos de un ilustrador francés que asentó las líneas de la mujer art déco en la Europa de entreguerras: George Barbier, cuyos diseños para Falbalas et Fanfreluches. Almanach des modes (1922-1925) causaron auténtico furor en la época. En este almanaque aparecían con mucha frecuencia parejas conformadas por una mujer de aspecto típicamente femenino y otra vestida con un elegante esmoquin negro, un traje de marinero, una chaqueta o una

${ }^{7}$ Este tipo de confusiones eran, según explica Nerea Aresti, bastante frecuentes: «La moda de los años veinte había acortado distancias entre el aspecto físico de los hombres y el de las mujeres. Carmen de Burgos señalaba con preocupación que a veces costaba trabajo distinguir a la primera mirada a una mujer peinada a lo garçon, con blusa camisero, levita o smoking de corte inglés, sombrero masculino y falda estrecha, de un hombre barbilampiño, con gran cuello de sport y pantalón ancho» (102). 


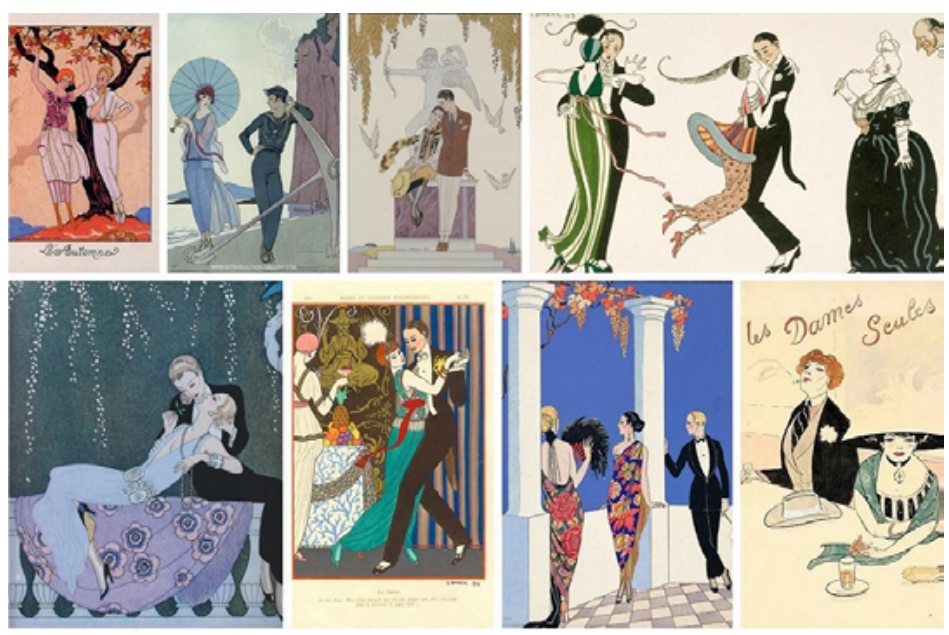

Imagen 1.

camisa de botones combinado con pantalones largos de pinzas... Esta última mujer lucía cabellos cortos, muchas veces engominados hacia atrás, cual dandi. Los colores sonrosados de las mejillas o el perfil tenue de las caderas, además de un cutis fino sin asomo de vello, hacían dudar al espectador: ¿son mujeres u hombres? Barbier hubiera podido dibujar a las dos muchachas que atraen poderosamente a María Luisa y casi parecen cobrar vida a través de los dibujos que adjuntamos (imagen 1).

En otra ocasión de su infancia, María Luisa asiste a un espectáculo de circo con su madre. Entre los números del programa se encuentran los equilibrios de una écuyère de larga melena rubia sobre un caballo blanco. El circo, que durante las vanguardias históricas fascinará tanto a artistas plásticos como a escritores por ser un espacio de libertad y subversión preñado de vidas alternativas, se revela aquí como un lugar para la fantasía y la ruptura con la norma ${ }^{8}$. María Luisa cae embelesada ante la joven amazona, y todavía más cuando la ve regresar a la pista vestida de muchacho, con calzón, chaqueta y sombrero:

A mí me gustaría saber montar a caballo... pero nunca me pondría gasas de bailarina sino traje de hombre... Cuando fuera mayor...

${ }^{8}$ No resulta baladí que, en la saga de Celia, la niña rompa con su vida reglada en el colegio de las monjas, donde la han internado sus padres, y escape con una compañía circense, viviendo todo tipo de peripecias. Se trata de una huida mental con tintes oníricos: la colegiala imagina qué ocurriría si se marchara en el carro de los titiriteros y lo escribe, durante un largo verano, en las páginas de un cuaderno en blanco. La primera parte del volumen Celia novelista (1934) recoge esta aventura de la protagonista con una troupe de artistas ambulantes. Remito a la edición crítica del texto para conocer más sobre el simbolismo y las implicaciones de este episodio (Mascarell, en prensa). 
- Eres una niña tonta... ¿Qué harás cuándo seas mayor?

- Vestirme de hombre y montar a caballo -declaré solemnemente, añadiendo que fuera de eso no me importaba nada-.

Mi madre aseguró que no se me podía llevar a ninguna parte porque luego no decía más que inconveniencias... Esa señorita que habíamos visto sería... ¡cualquier cosa! Nada bueno, de seguro (115).

Artista ambulante, travestida para salir a actuar y galopando sobre un caballo a toda velocidad -cómo no pensar en El deseo de ser piel roja, de Franz Kafka, en su intenso canto a la libertad absoluta del galope-: para la madre, esa écuyère es portadora de demasiados elementos peligrosos para la moral femenina cristiana.

El vestuario, el deseo, la libertad de construirse como sujeto y la orientación sexual -vinculada a la represión social y familiar-se entremezclan en Oculto sendero, y hay un capítulo que lo emblematiza como ningún otro: "Carnaval» (159-172). A lo largo de su infancia y adolescencia, María Luisa apenas se topa con figuras benefactoras. Una de ellas, la entrañable tía Manuelita, si bien no acaba de comprender la terquedad y las extrañas manías de su sobrina, al menos la respeta, ayuda y trata con cariño. Todavía convaleciente por el sarampión, la pequeña escucha estas palabras en boca de su tía: «Si eres buena y no te excitas y estás tranquila para que no te suba la fiebre, te disfrazaré de aldeano holandés con el traje que tengo de mi Julianito... ¿Quieres?». Y escribe María Luisa: «Sí, sí; yo quería. Quería tan apasionadamente que se me quitó el apetito y el sueño y de madrugada tuve calentura...» (167).

Los preparativos para el Carnaval, la fiesta del travestismo, institucionalizado y bendecido una vez al año, se hacen eternos para la cría, que aguardaba con deleite el momento de verse ataviada de hombre. Llega el día:

Por fin, metí mis piernas en los anchos calzones de holandés... El perfume del traje me envolvió como un alma nueva que se abrazaba a la mía... Me contemplé en el espejo... Yo era un holandés, con su pipa... jun holandés de verdad! Puse las manos en la espalda y crucé por delante del espejo dando zancadas... (167).

En la fiesta de Carnaval de un café de la carrera de San Jerónimo, «iTodas creían que yo era un niño! Esto me entusiasmaba de tal manera, que hacía lo posible por imitar los gestos de los chicos, estirando los brazos y poniéndome a horcajadas sobre la silla». Sin embargo, al regresar a casa le espera un gran disgusto: su madre, fosca desde que la ha visto salir vestida de holandés, se encuentra enferma en la cama y, tras varios improperios, arremete duramente contra su hija para humillarla: «iSi te figuras que estás muy guapa...! Eres muy fea, hija mía, y por mucho que te compongas lo serás siempre...». El precioso disfraz es devuelto a Manuelita, y con él, la ilusión de la niña por compartir sus emociones con una madre intolerante, que detecta la querencia de la criatura por seguir derroteros antinormativos y quiere ponerle cortapisas.

Este episodio del disfraz de holandés, del placer que a María Luisa le proporcionaba llevarlo puesto y mirarse así ataviada, enlaza con un precioso recuerdo de infancia descrito por Victorina Durán en sus memorias: 
Los disfraces del carnaval. A los nueve años me vistieron de moro. ¡Qué feliz fui! Los calzones rojos, bombachos hasta el tobillo, babuchas en los pies, blusa blanca, una torerita roja con adornos de lentejuelas, una faja de raso ancha donde llevaba un alfanje [...]. Creo que es el traje con el que me he sentido más cómoda en toda mi vida; tanto que, por las tardes, al llegar del colegio, me lo ponía enseguida. Como este traje me convertía en un moro notable, cuando venían amiguitas a jugar conmigo, ya sabían todas que pertenecían a mi harén y el juego siempre era a base de esto... (145).

El disfraz como máscara que expresa más verdad que la máscara cotidiana, que esa máscara impuesta por el sistema heteropatriarcal y sin la cual se acaba en el lado oscuro de los disidentes, marginados o raros. Sin embargo, los ambientes lúdicos -las fiestas del Carnaval, los juegos infantiles, el teatro...- admiten las transgresiones momentáneas, las toleran como vías de escape antes de regresar a la «normalidad» pautada. ${ }^{9}$ En virtud de este contexto, hace su aparición simbólica el disfraz masculino de rasgos fuertes - un holandés con pipa, en el caso de María Luisa; un moro con alfanje, para Victorina-, cargado de connotaciones de éxito y de liderazgo, y poseedor de un emblema rotundo: los calzones y sus posibilidades para la intrepidez. En una novela interesantísima publicada en Alemania en 1933, Muchachas de uniforme, la protagonista debe representar un papel masculino en una función teatral de la escuela donde vive interna. Christa Winsloe narra en esta obra el enamoramiento de la discípula Manuela y una de sus profesoras, y las consecuencias trágicas para ambas de este sentimiento. La joven queda fascinada al ponerse unos pantalones, mirarse en el espejo y ponerse en movimiento:

Manuela estaba frente al espejo, mirando a los ojos su reflejo. Llevaba el pelo suelto y el jubón le sentaba de maravilla. Al no llevar falda, parecía más alta. Hasta andaba de otra forma. Qué responsabilidad. Pero era fantástico sentirse así de libre. Ya no le molestaba la falda cuando tenía que apoyar el pie sobre una silla para atarse los cordones y podía usar las piernas de forma totalmente distinta. ¡Qué soltura, qué libertad de movimientos! Tuvo la sensación de estar transformándose poco a poco en Nérestan (213).

Asimismo, recordemos que el personaje de Celia, con rasgos también de chicazo -aficionada a los juegos alborotados, metomentodo, traviesa, audaz, sin pizca de coquetería...-, es escogida en el colegio de las monjas para interpretar a Blas, un pescador de ideología comunista que acaba rendido a los pies de la Virgen: «Yo estaba hecha una facha, con la blusa larga y las bocas de los pantalones prendidas al vestido. Además, me pegaron con goma barbas y bigotes, y me tiraban tanto de la piel, que no podía dejar de hacer guiños. Todas se reían de mí» (Fortún, Colegio 132).

9 Lo sabían bien las modernas estudiantes de la Bauhaus de Alemania (1919-1933) y las de la Residencia de Señoritas (1919-1939) en España: ambos grupos emplearon profusamente el disfraz para la inversión de los géneros en sus fiestas y celebraciones (Mascarell 2020). 
Pese al humorismo de la escena, resulta significativo que el único papel masculino de la función se le atribuya a Celia.

Precisamente, la hermana de Cuchifritín suele ser calificada por su familia de «novelera», dada su inclinación por aplicar la lógica de los cuentos maravillosos a los episodios de su vida diaria - con las disparatadas consecuencias que implica la mezcla de realidad y ficción-. También la madre de Oculto sendero afirma sobre su hija que "es muy novelera». En efecto, la mente de María Luisa, tan proclive a la fantasía y al ensueño como la de Celia, encuentra un goce particular en la lectura en familia de una novela que hace sus delicias a causa del particular perfil de la protagonista:

La novela se titulaba Los héroes, trataba de la conquista de América, y había una india preciosa que, vestida de hombre, era el paje de don Lope [...]. El paje Luis constituía mi entusiasmo aquellos días. Yo quería ser como ella, vestirme como ella, y mientras duraba la lectura creía ser ella misma (200).

La india cazaba, participaba en las reyertas masculinas, disparaba con acierto y era estimada entre la tropa por su valentía... Con su atuendo masculino, logra ser respetada y libre. María Luisa, que aprecia estos rasgos y admira el carácter de la gallarda muchacha, acaba presa de una grandísima decepción cuando, hacia el final de la novela, el paje Luis aparece vestida de mujer y se casa con un capitán de los tercios del rey, "grande como un gigante y muy bárbaro». La niña llora sin consuelo ante el desenlace matrimonial de sumisión femenina que le espera, incluso, a las mujeres más bizarras.

Si la niñez de María Luisa está marcada por múltiples episodios de tristeza, soledad e incomprensión, la adolescencia está cuajada de profundas decepciones y angustiosos temores. Cuanto más a fondo conoce el funcionamiento del mundo adulto, más lo aborrece y teme María Luisa. En plena pubertad, su apego a una estética sobria, poco femenina y sin aderezos superfluos se agudiza. Merece la pena recoger algunas de sus opiniones en este sentido:

Yo estaba muy contenta de que se hubiera muerto el abuelito, porque ahora me iban a poner de luto y mamá le quitaría las puntillas al vestido azul y no me haría ponerme el sombrero de pájaros (142).

De mi indumentaria estaba francamente satisfecha este año. Mamá me había hecho tres blusitas camisero, con puños, gemelos y chalina negra. Estas camisas con falda gris o negra componían mi alivio de luto y me daban un aire, en mi extrema delgadez y desgarbado crecimiento, un poco andrógino, que me encantaba sin saber por qué (189).

Pese a la presión del ambiente tradicional en el que vive inmersa, María Luisa persiste durante toda su adolescencia en lucir un vestuario lo más sencillo y discreto posible. La tía Manuelita, en un intento de socialización para la sobrina, le ofrece una maleta repleta de cintas, broches y adornos para componer su atuendo y asistir a la verbena del pueblo con sus amigas. Las chicas se muestran encantadas con las fruslerías que decoran sus vestidos y cabellos; sin embargo, María Luisa declara con enojo: «Llevé un lazo de a cuarta sobre el moño y tuve toda la tarde el conven- 
cimiento de estar hecha un adefesio» (281). La realidad es que la joven nunca llega a encajar con la pandilla del pueblo donde transcurre su adolescencia, y la causa se encuentra en su identidad forjada sobre una conducta atípica -alejada de la docilidad y la dulzura esperables en una chica de su época- y una parca indumentaria, que recordaba a la estética de un chico:

Una tarde paseaba con unas amigas y unos cuantos muchachos pretendientes de algunas de ellas. Yo tenía entre el grupo masculino pocas simpatías. Los hombres siempre vieron en mí un ser extraño, poco femenino, al que gustaban de humillar como si sospecharan en mí cierta rivalidad ridícula... ¡Yo sí que les envidiaba! ¡Su libertad, sus trajes sencillos, estrictos, sin ninguna fantasía, su derecho de comportarse naturalmente, sin afectación...! (267).

La libertad es el bien más ansiado por la protagonista de Oculto sendero. De hecho, la María Luisa ya esposa y con una hija envidiará a las jóvenes de los años treinta, las muchachas que crecen bajo el auspicio igualitario de la Segunda República, y escribirá:

¡Libertad! ¡Libertad! Ser como el aire, a quien nadie pregunta a dónde va ni de dónde viene... ¡ $\mathrm{Ah}$, las muchachas modernas! Las veía solas por la calle, con su cartera bajo el brazo, camino de la universidad, del instituto, de la escuela... ¿Por qué había venido yo al mundo diez ańos antes de tiempo? (363).

María Luisa se fustiga con esta pregunta cuando ya es una mujer casada, asimilada a la vida doméstica y al cuidado de un marido ególatra, celoso e incapaz de empatía para con su esposa, poseída por unos deseos de libertad que a duras penas logra reprimir. Entre los golpes que les depara la vida, el más terrible será la pérdida de una hija a temprana edad -también Fortún perdería a su hijo Bolín con tan solo diez años de edad-. Para tratar de superar el dolor, Jorge y María Luisa deciden trasladarse de Madrid a las Palmas de Gran Canaria y cambiar de aires. Allí se encuentran con una sociedad sensual, hedonista y volcada en la crianza de los hijos. No tardan en establecer relaciones sociales y en ser invitados a actos y cenas. En medio de un banquete, María Luisa se sofoca, se levanta para ir a refrescarse y entonces conoce a la periodista y poeta Fermina Monroy, más conocida como Fermín:

Al mismo tiempo que yo, se levantó del extremo de la mesa un muchacho joven. [...] Hice amistad con aquella señora - ¡no era un muchacho!- vestida con traje sastre, corbata masculina y pelo cortado y pegado a la redonda cabeza.

- Fermina Monroy -me dijo, presentándose con desenvoltura-, treinta y cinco ańos, soltera y nacida en la isla... [...]. La vi a usted el día que desembarcó... Llevaba usted ese mismo traje negro, camisa de seda gris y fieltro... Entre aquel grupo de señoras vestidas de papagayos, se veía... lo que era usted... iperdone, si la molesto! Me dije: tienes una amiga más.

- Visto siempre de negro desde hace años...

- No es el color, es el corte... ¿se lo ha hecho un sastre?

- Sí... el mismo de mi marido... (378-9). 
María Luisa no entiende el código ni la interpretación: está lanzando un mensaje con su cuerpo sin haberlo filtrado previamente por la razón. No comprende que su vestimenta expresa de ella aquello que ni siquiera se atreve a pensar ni a verbalizar. La estética con la que se atavía se ha anticipado a su proceso de autoconocimiento consciente. Sin embargo, la potente carga semiótica de su vestuario no pasa desapercibida a los ojos de los demás. En este sentido, la teórica de la moda Claudia Fernández-Silva explica bien el potencial comunicativo de la ropa que llevamos y a través de la cual nos perciben y descodifican los otros:

Al vestirnos, preparamos nuestro cuerpo para el mundo social; por medio de la ropa que elegimos y su combinación creamos discursos sobre el cuerpo: aceptable, respetable, deseable, violento o abyecto. Nuestro modo de vestir denota indefectiblemente una toma de posición, tanto en un sentido de inclusión (a un grupo, una identificación con un género musical), de exclusión o diferenciación frente a un referente establecido (familia, compańeros de estudio, otros jóvenes del barrio). De esta manera, como artefactos culturales, el vestuario y los diferentes elementos de decorado corporal se convierten en vehículos de expresión, símbolos de identidad y declaraciones de una preferencia estética; nuestros cuerpos vestidos hablan y revelan una cantidad de información sin mediación de las palabras (47).

Fermín, experimentada y libre, lee los signos del vestuario de María Luisa-el traje negro, la camisa de seda gris, el corte del sastre, los cabellos de muchacho...- y concluye que se encuentra ante "una amiga más». Al saberla casada, no puede evitar pronunciar unas palabras que dejan extrañada a la madrileńa: «iQué desastre es una mujer como nosotras casada! Un verdadero desastre...». María Luisa, en su fuero interno, opina: «¿Por qué me comparaba con ella? Como no fuera porque las dos nos vestíamos lo mismo no podía comprender qué nos unía» (380). Efectivamente, el único vínculo que María Luisa es capaz de detectar entre ambas es la forma de vestir, al menos al principio... Porque esa forma de vestir andrógina es la espita por la que se ha ido filtrando, desde niña, su orientación sexual y su deseo hacia otras mujeres.

Las islas jugarán un papel decisivo para María Luisa en el descubrimiento y la aceptación, nunca exenta de dudas y de dolor, de su lesbianismo. Poco a poco, se aproximará a un círculo de gais y lesbianas con los que iniciará una amistad decisiva para su complicado futuro de emancipación. En ese grupo canario de artistas, la protagonista encontrará un alma gemela en Lolín, también fatalmente casada como ella, y también pintora. Pero Lolín mantiene una relación amorosa con Rosita, recitadora profesional de poesía, a quien un día acuden a recoger al muelle: «Mi amiga, nerviosa, se apartó de mí y la contemplé un momento, con su chaqueta ajustada, la camisa de seda blanca... y al aire su cabeza rizada de muchacho...» (398). María Luisa observa a su amiga y la identifica, como anteriormente había hecho Fermín, con una lesbiana, una mujer que espera con ansia la llegada de otra mujer a la que ama.

Por supuesto, Jorge ve con malos ojos las nuevas amistades de su esposa y el consecuente distanciamiento que implican para unos cónyuges que, a excepción del breve tiempo del noviazgo, nunca han estado bien avenidos. Además, la peculiar estética andrógina de María Luisa se ha ido acentuando en paralelo a la adquisición de una mayor libertad de movimiento - su trabajo como pintora de abanicos 


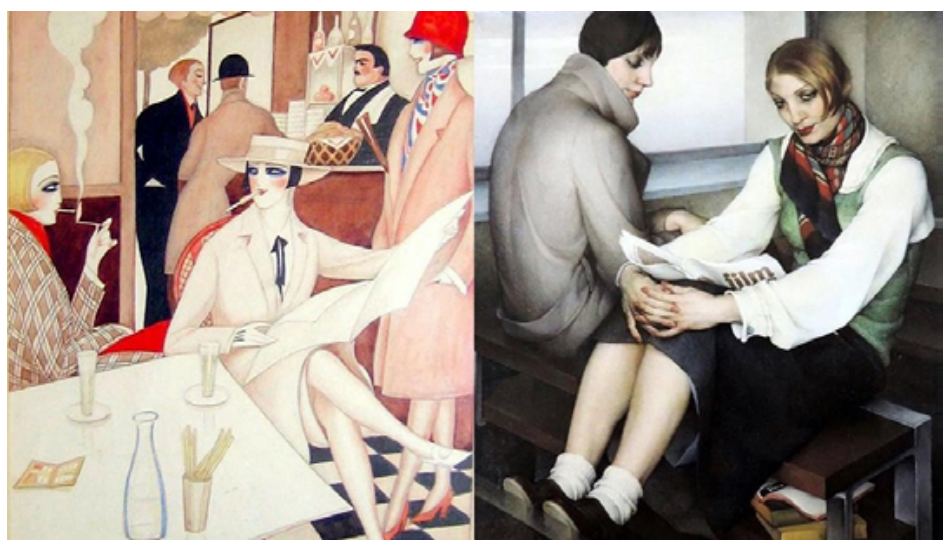

Imágenes 2 y 3 .

le reporta sus primeras ganancias económicas- y de experiencias afectivas y sexuales con mujeres.

Cuando María Luisa, en un último intento por salvar su matrimonio, deja atrás el ambiente sáfico de Canarias y regresa con Jorge a Madrid, expone con tono de sacrificio el reto que se propone: «Mañana me compraría una blusa de seda, me pondría pendientes... sería ¡una mujer!». Cree que vistiéndose y adornándose con prendas típicamente femeninas regresará al seno matrimonial convertida en lo que ella llama una mujer, es decir, una mujer heterosexual, dócil, sumisa y resignada a una vida de secundaria sin aspiraciones ni deseos propios. Se arregla para ir a recoger a Jorge a la estación: «El cabello bien cepillado para que brillaran los reflejos dorados de las ondas, las uñas bien pulidas... Estrenaba medias, zapatos y la blusita de fantasía comprada por la mañana. Llevaría el abrigo de entretiempo al brazo...» (435). A Jorge no le pasa desapercibido el cambio estético, e interpreta la acentuación de una feminidad prototípica como la voluntad de acercamiento de su esposa, como el acatamiento de su rol de compañera sexual: «Pero ¡qué guapa te has puesto!», murmura con ardor, y sus ansias de gozar de María Luisa no tardan en materializarse en un episodio de cama al llegar a casa. Este será un punto de inflexión en la vida de la pintora. El reconocimiento definitivo del horror que ha supuesto para ella, a lo largo de su vida, mantener relaciones sexuales con un hombre sin sentir ningún deseo por él. A partir de aquí, la separación de la pareja se vuelve irreversible y culmina en el divorcio final.

A lo largo de este repaso a Oculto sendero, se han venido destacando las distintas escenas donde aparece la imagen de una mujer con rasgos o aspecto masculinos (imágenes 2 y 3 ).

Me gustaría detenerme ahora en las pinturas de arriba. A la izquierda, se ofrece un dibujo de Gerda Wegener, la pintora danesa célebre por haber sido la esposa de la primera persona transexual de la historia, Lili Elbe. La ilustración muestra una cafetería de ambiente gay, donde dos amigas comparten mesa, cocktail, ciga- 

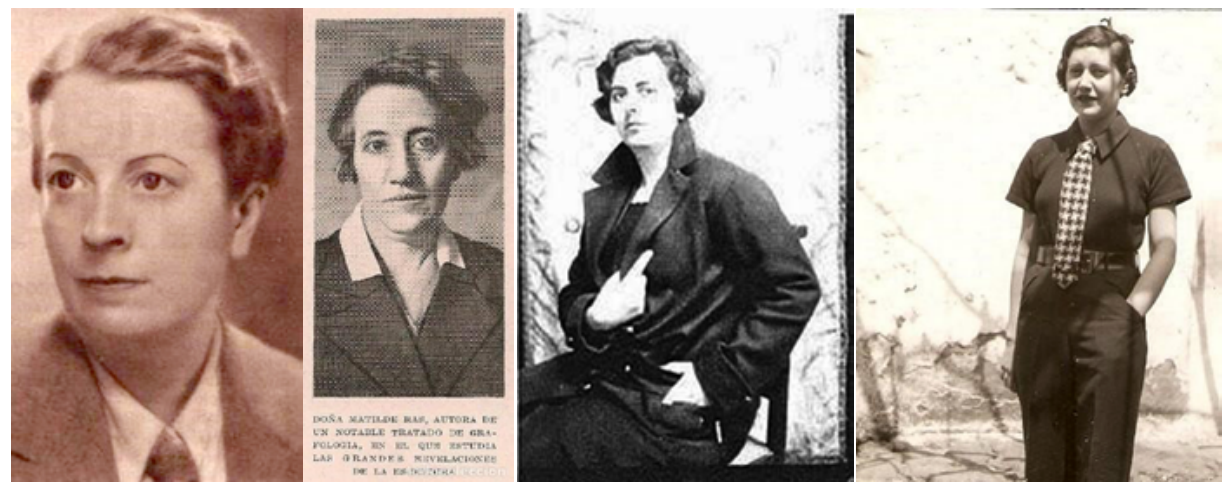

Imágenes 4, 5, 6, y 7 .

rrillo e intensidad en el cruce de miradas. La que sostiene el diario presenta rasgos andróginos: el sombrero masculino, la corbata, una corpulencia destacable... A la derecha, el cuadro titulado Las universitarias (1934), donde una muchacha de pelo a lo garçon nos mira seria y desafiante, tras haber despegado sus ojos de una revista sobre cine. A su lado, otra joven de aspecto andrógino, con amplia gabardina gris sobre una espalda musculosa -como la de María Luisa-, observa a su compañera por el rabillo del ojo. Debajo de los bancos sobre los que están sentadas, libros, en señal inequívoca de estudio y cultura.

Ambas obras brindan un retrato de la denominada «mujer nueva» $\mathrm{O}$ «mujer modern» ${ }^{10}$ icono femenino y fenómeno cultural que se extiende por toda la Europa de entreguerras:

La mujer moderna era el símbolo por excelencia de la revolución sexual de la década de 1920. Con su pelo corto, la famosa Bubikopf era esbelta, atlética, atractiva y carente de instinto maternal, fumaba y, a veces, vestía con prendas masculinas; salía sola y practicaba el sexo cuando le apetecía; trabajaba, normalmente en una oficina, o se dedicaba al arte, y vivía al día, con total independencia (Weitz 355).

La imagen de la «mujer moderna» se asocia con las prendas masculinas. Arriba (imágenes 4, 5, 6, y 7), las fotografías (de izquierda a derecha) de Elena Fortún, su amiga la grafóloga Matilde Ras, la escenógrafa y figurinista Victorina Durán y la periodista Josefina Carabias muestran ese toque andrógino que lucía, también en España, la mujer culta, profesional y vinculada al mundo de las artes. En efecto, una cierta ambigüedad sexual formaba parte de la identidad de grupo de las mujeres de la vanguardia española.

10 Para indagar más en torno a la iconografía de la mujer moderna en España, véase el artículo de Begoña Barrera (2014). 

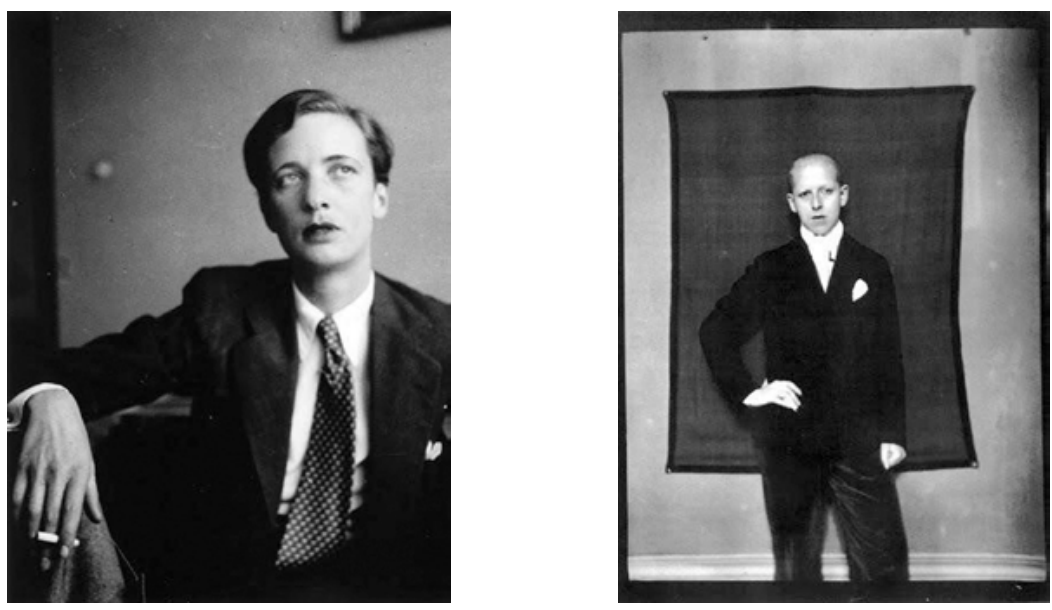

Imágenes 8 y 9 .

Apunta Estrella de Diego que "solo hay algo más femenino que una mujer y más masculino que un hombre: su esencia, sus rasgos sobresalientes» (26). Por eso no extraña que las corbatas, las solapas de las americanas o los pantalones de corte recto, sobre los cuerpos de estas mujeres, nos remitan a la masculinidad, nos ofrezcan la siempre perturbadora y fascinante visión de lo andrógino. Un viraje de la identidad femenina que se observa en la imagen de otras mujeres fundamentales de la modernidad, como la periodista y viajera Annemarie Schwarzenbach o la surrealista francesa Claude Cahun ${ }^{11}$. Arriba (imágenes 8 y 9), sus fotografías: cabellos cortos, camisas, trajes, corbatas, cigarrillos y actitud seria o distante que no busca la complacencia del espectador.

La imagen andrógina se revela como el mejor símbolo estético de la libertad de la mujer, de su emancipación profesional y de su autonomía vital. Así, la mujer moderna desarrolla modelos identitarios alejados del ideal de la perfecta casada y madre, y se inspira, para construir su apariencia, en la estética de aquellos que dominan el espacio público y ejercen como figuras de poder: los hombres. No extraña, por tanto, que la moderna o garçonne sea, en muchos casos, la encarnación de la masculinidad en un cuerpo de mujer: una imagen revolucionaria en línea con la revolución que suponía su acceso a la esfera laboral, artística, universitaria... hasta

11 Muy recomendables son dos novelas contemporáneas que recrean la vida de estas dos artistas y precursoras. Me refiero a Ella, tan amada, de la autora italiana Melania Mazzucco, publicada por Anagrama en 2006 y dedicada a la apasionante vida de la melancólica Schwarzenbach, y a la novela Nadie más que tú, de Rupert Thomson, editada por Galaxia Gutenberg en 2019 y centrada en la relación entre Cahun y la artista Marcel Moore. 
entonces vetada para ella. El pelo corto, los pantalones o el cigarrillo entre los dedos iba unido a conducir un coche, trabajar para obtener el sustento propio, disfrutar del tiempo libre en cafeterías o actos culturales, ser soltera y no vivir subyugada por la familia o la crianza. El tipo de vida que sí estaba permitido para los hombres. El tipo de vida que ansiaba María Luisa y por el que, al final de la novela, decide apostar, pese a la condición de "paria» u outsider en la que queda subsumida:

¡Cuando mis cuñados sepan mi marcha... que calificarán de escapatoria...! Oigo a mi cuñado Antonio hacer literatura: «Vuelve a tu hogar, mujer, esposa, dueña y señora, vuelve a tus deberes, con los tuyos...» ¡No! Los míos son esos que despreciáis, Joaquinito, Fermina, Lolín, Rafita... los parias de una sociedad normal que no tiene otro fin más que reproducirse, los que habéis echado de vuestras honradas casas, llenas de lujuria, lloros de chicos y olor de pañales... Ellos son mis compańeros de camino y me voy con ellos... (494).

Por supuesto, el sistema patriarcal percibía como un peligro para el statu quo imperante la difusión de los valores de la mujer nueva. Su inversión o subversión de los géneros tradicionales ponía en solfa el orden de privilegios construido sobre la superioridad masculina. Por eso se denostó a la mujer moderna y a su incómoda imagen ambigua, y por eso con frecuencia se la catalogó dentro del denominado "tercer sexo", una etiqueta o categoría cargada de connotaciones peyorativas o, como mínimo, ridículas. Este tercer sexo era el síntoma de una crisis profunda del patriarcado y resultaba, por tanto, problemático. El miedo al cambio alimentaba el odio hacia todo lo que rehuía constreñirse dentro de la feminidad tópica y los valores hegemónicos. Nerea Aresti lo explica así:

El feminismo hominizante, la homosexualidad, la moda andrógina y la crisis de la institución matrimonial formaron un conjunto de elementos unidos íntimamente. [...] El tercer sexo podía ser la feminista marimacho, la mujer emancipada, la coqueta, la garçon, el homosexual, la sufragista solterona, la lesbiana. Era notoria la dificultad para deslindar fenómenos de naturaleza tan diferente como corrientes de la moda, tendencias sexuales, opciones ideológicas, estado civil o situación profesional. El tercer sexo resultaba ser, en definitiva, todo aquello que no respetaba los modelos sexuales, masculino y femenino, definidos de acuerdo a los criterios tradicionales (102).

Esa pugna entre tradición y modernidad, entre sometimiento femenino al varón y libertad para construirse a sí misma, atraviesa la existencia de María Luisa -trasunto literario de Elena Fortún-, atrapada en un matrimonio que representa una cárcel para ella. Su personalidad íntima, sus auténticos deseos, emergen a través del vestuario andrógino, se proyectan en aquellas mujeres que lo exhiben a su vez. María Luisa se enamora de la imagen de la mujer moderna y de su significado al ver a la primera pareja de lesbianas con la que se cruza en su vida, en aquel restaurante al que acude con su familia. Durante la infancia, el paje Luis o la amazona del circo son mujeres travestidas de hombre que ejercen una poderosa atracción sobre la nińa, fascinada por la mujer de aspecto fuerte y varonil. A medida que crece, su 
forma de ir vestida simboliza el deseo de ruptura con los moldes establecidos: desde el odiado vestidito de volantes hasta el disfraz de marinero holandés, pasando por el sobrio vestido de luto, que le encanta llevar. Progresivamente, María Luisa se irá decantando por lucir una estética de mujer moderna. En Canarias, le dicen: «Vas vestida de una manera que llama la atención", aunque ella nunca lo hubiera dicho. Durante toda la novela, vestir «diferente» es la forma que tiene María Luisa para manifestar su descontento hacia las normas heteropatriarcales y para situarse fuera del asfixiante canon de la feminidad. Sus blusas camisero, su apego por el blanco, el negro y el gris, sus trajes cortados por el sastre del marido son los emblemas que la entroncan dentro de una genealogía de la modernidad femenina en la cual, gracias a autoras precursoras como Elena Fortún, hoy podemos inscribirnos en libertad las mujeres. 


\section{OBRAS CITADAS}

Albarracín, Matilde. «Identidad(es) lésbica(s) en el primer franquismo», en Osborne, Raquel (ed.), Mujeres bajo sospecha. Memoria y sexualidad 1930-1980. Madrid: Editorial Fundamentos, 2012, pp. 69-88.

Aresti, Nerea. Médicos, donjuanes y mujeres modernas. Los ideales de feminidad y masculinidad en el primer tercio del siglo XX. Bilbao: Servicio Editorial de la Universidad del País Vasco, 2001.

Barrera López, Begoña. «Personificación e iconografía de la mujer moderna. Sus protagonistas de principios del siglo xx en Espańa», Trocadero, 26 (2014), pp. 221-240.

Capdevila-Argüelles, Nuria y Fraga, María Jesús (eds.). Elena Fortún y Matilde Ras. El camino es nuestro. Madrid: Fundación Banco de Santander, 2015.

Celaya Carrillo, Beatriz. La mujer deseante: sexualidad femenina en la cultura y novela españolas (1900-1936). Juan de la Cuesta, 2006.

Diego, Estrella de. El andrógino sexuado. Eternos ideales, nuevas estrategias de género. Madrid: La balsa de la Medusa, 2018.

Dorao, Marisol. Los mil sueños de Elena Fortún. Cádiz: Alboroque, 1999.

Durán, Victorina. Mi vida, 1, 2 y 3. Madrid: Residencia de Estudiantes: Madrid, 2018.

Fernández-Silva, Claudia. De vestidos y cuerpos. De vestidos y cuerpos. Medellín: UPB, 2013.

Fortún, Elena. Celia en el colegio. Madrid: Alianza, 1992.

Fortún, Elena. Celia novelista. Mascarell, Purificació (ed.), Sevilla: Renacimiento, en prensa.

Fortún, Elena. Oculto sendero. Capdevila-Argüelles, Nuria (ed.), Sevilla: Renacimiento, 2016.

Halberstam, Judith. Masculinidad femenina. Madrid-Barcelona: Egales Editorial, 2008.

Marañón, Gregorio. La evolución de la sexualidady los estados intersexuales. Madrid-J. Morata, 1930.

Mascarell, Purificació. «Las mujeres de la Bauhaus y la Residencia de Señoritas. Estudio comparativo de la modernidad femenina a través de la modernidad gráfica», en XI Congreso Internacional de AUDEM, 2020 (https://www.youtube.com/watch?v=RIxWAWgQB_o\&t=2s).

Ras, Matilde. Diario. Sevilla: Renacimiento, 2018.

Weitz, Eric D. La Alemania de Weimar. Presagio y tragedia. Madrid: Turner, 2009.

Winsloe, Christa. Muchachas de uniforme. Zaragoza: Xórdica, 2019. 
